\title{
The Communist Party of Indonesia
}





\section{DONALD HIN DLEY}

\section{The Communist \\ Party of Judonesia \\ 1951-1963}

UNIVERSITY OF CALIFORNIA PRESS

Berkeley and Los Angeles

1964 
UNIVERSITY OF CALIFORNIA PRESS BERKELEY AND LOS ANGELES CALIFORNIA CAMBRIDGE UNIVERSITY PRESS LONDON, ENGLAND

(C) 1964 BY THE REGENTS OF THE UNIVERSITY OF CALIFORNIA

LIBRARY OF CONGRESS CATALOG NO:: 64-24889 PRINTED IN THE UNITED STATES OF AMERICA 
PARA LOS DE ABAJO 
